Animal Health Research Institute, Dokki

Port-Said Laboratory for Food Hygiene.

\title{
OCCURRENCE OF LIPOLYTIC AND PROTEOLYTIC FUNGI IN LOCALLY SMOKED FISH
}

(With 5 Tables)

\author{
By \\ ZIENAB I. SOLIMAN and AMANY M. SHALABY \\ (Received at 13/2/2008)
}

تواجد الفطريات المحلة للاهون والبروتين فى الأسماك المدخنة المحلية0

$$
\text { زينب إبراهيم سليهان ،أمانس محمود شلبى }
$$

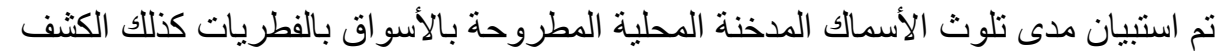

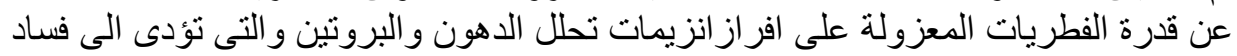

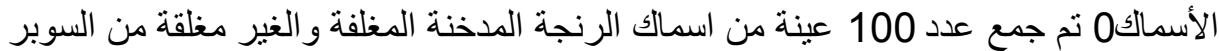

ماركت المختلفة فى مدينة بورسعيد 0 و اسفرت نتائج الفحص ان نسبة كبيرة من العينات

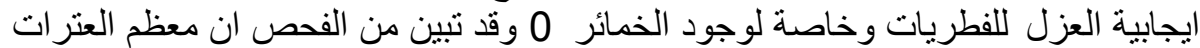

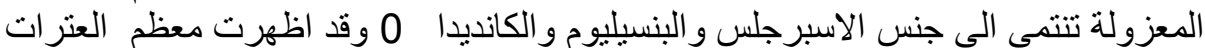
المختبرة القدرة على تحلل الدهون و البروتين بنسب متفاوتة قد تصل فئ في بعض العن العتر ات من

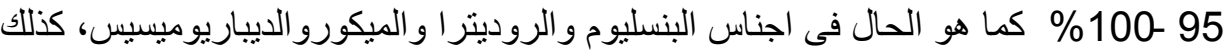

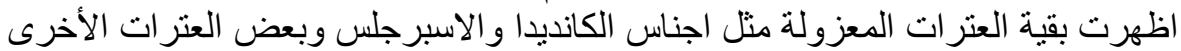
نتيجة ايجابية لتحلل البروتينات و الدهون بنسب مختلفة مما يدل على الدور الذئ تلعبه تللك

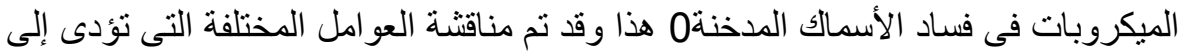
زيادة نمو تلك الميكروبات و أثر ها على الصحة الصاد العامة

\section{SUMMARY}

A total of 100 of locally smoked fish samples, packed in polythene bags or unpacked (50 of each) were subjected to mycological examination. The proteolytic and lipolytic potentials of fungi isolates associated with examined smoked fish were investigated. The incidence of yeast was higher than mould in either packed or unpacked smoked fish samples. Aspergillus and Pencillium spp. were the dominant mould groups, irrespective of the packed or unpacked samples. Other moulds isolated were Eurotium, Fusarium, Mucor and Cladosporium species. The predominant yeast species was Candida followed by Debaryomyces spp., Rhodotroula spp. and Saccharomyces spp. The protease and lipase producing potential of the isolates varied among the genera and between 
isolates of the same species. Among the isolates, strains of $P$. expansum, $P$. viridicatum, Mucor, Rhodotroula and Debaromyces spp. demonstrated the most noticeable proteolytic activity with a percentage reach up $100 \%$, followed by strains of $A$. niger and $A$. flavus. The majority of tested mould and yeast isolates were showed lipolytic activities. The existence and growth of these fungi on smoked fish is a pointer to the potential health risk associated with the consumption of smoked fish. Their ability to elaborate protease and lipase may also an indication of their active role in the spoilage of smoked fish.

Key words: Fungi, smoked fish, mould, yeast

\section{INTRODUCTION}

Smoking is one of the oldest methods of preserving fish, or any other meats for that matter. Long before there were no refrigerators and freezers, fishing ancestors learned to use a combination of salt and smoke to keep fish from spoiling. Today, smoking is no longer necessary, but it remains popular for the flavor it gives to fish. Smoking methods vary, but all are based on a few common principles. First, the fish is treated with salt, either in the form of strong brine or a surface coating of dry salt. Most fish are given a second cure after the initial salting to add additional flavors. After curing, the fish is rinsed to remove the salt and other curing ingredients from the surface, then allowed to dry in cool flowing air until a shiny, slightly tacky skin (pellicle) forms on the surface. The actual smoking takes place inside a chamber filled with smoke from smoldering hardwood. At this point the process diverges; fish are either "hot-smoked" or "cold-smoked," depending on the temperature of the smoking chamber. The choice determines the texture, flavor, and potential uses of the fish (AFDO, 1991).

From the processing to the market, smoked fishes are often contaminated with microorganisms including mould and yeast (Okafor and Nzeako, 1985 and $\mathrm{Wu}$ and Salunkhe, 1978). Fungal contamination is considered the main spoilage agent of smoked fish, impart musty offflavour, sliminess, lipolysis and unpalatable taste that render the products of inferior quality, unmarketable or even unfit for human consumption (Stoskopf et al., 1993). The spoilage of smoked fish during storage is considered an important and dangerous problem facing smoked fish producers. Smoked fish are more susceptible to hydrolysis and oxidation due to lipolytic moulds and yeasts which are capable of 
causing these deteriorations (Ward and Baaji, 1988). The degree of spoilage of yeasts and moulds isolated from protein - rich foods such as sea foods, can be estimated according to the proteolytic activity of the isolated fungi (Kobatake et al., 1992).

In view of this concern, the present work was carried out to investigate the degree of fungal contamination in smoked fish and to throw the light on the proteolytic and lipolytic potentials of fungi associated with smoked fish.

\section{MATERIALS and METHODS}

\section{Samples Collection:}

A total of 100 locally smoked Herring fish samples, 50 each from, packed in polythene bags and unpacked, were collected randomly from retail markets of different sanitation levels in Port Said City. The collected samples were dispatched directly to the laboratory in an ice box where they were prepared and examined.

\section{Mycological examination:}

\subsection{Preparation of homogenate:}

Fish sampling and preparation of sample homogenate were carried out according to the technique recommended by Andrews and Hammack (1998).

\subsection{Enumeration of total moulds and yeasts:}

The mould and yeast contamination levels of the examined samples were determined by using dilution plate technique. Malt extract agar (Difco) and potato dextrose agar (Difco) plates with added $100 \mathrm{ppm}$ Chloramphenicol were inoculated with appropriate dilutions (Tournas et al., 2001). The plates were incubated at $28^{\circ} \mathrm{C}$ for one week at which resulting fungal colonies were counted separately by naked eye and the mould and yeast counts per gram were calculated and recorded.

On the other hand, colonies with different morphological characters were inoculated on appropriate media for purification and isolation.

\subsection{Identification of the isolates:}

Identification of the mould genera and species based on macroscopical and microscopical features was carried out according to the recommended methods outlined by Pitt and Hocking (1985) for penicillia, Raper and Fennell (1965) for aspergilli. Other Deuteronomycetes, Ascomycetes and Zygomycetes were identified as reported by Samson et al. (1981) and Pitt and Hocking (1985). 
Besides, the isolated yeasts were identified according to the technique recommended by Campbell et al. (1980).

\section{3-Determination of proteolytic activity of the fungal isolates:}

Proteolytic activity of fungi was determined as described by ICMSF (1978). Each fungal isolate was inoculated on the surface of skim milk agar in which skim milk was added just before pouring the medium into the Petri- plates. Plates were incubated for 7 days at $28^{0} \mathrm{C}$; afterwards, the clear zones of hydrolysis (degradation of milk protein around the colony) were measured and recorded as zone of hydrolysis.

\section{4-Determination of lipolytic activity of isolates (Koburger and} Jaeger, 1987)

Each mould or yeast isolate was inoculated on the surface of tributyrin agar plates. The inoculated plates were incubated at $25^{\circ} \mathrm{C}$ for one week. Yeast or mould colonies showing lipolytic zone were recoded.

\section{RESULTS}

Table 1: Statistical values of total mould count in the examined smoked fish samples ( $\mathrm{n}=50$ each).

\begin{tabular}{|c|c|c|c|c|c|}
\hline \multirow{2}{*}{ Smoked fish } & \multicolumn{5}{|c|}{ Mould count (cfu/g) } \\
\cline { 2 - 3 } & \multicolumn{2}{|c|}{ Positive } & Min & Max & Mean \pm SE \\
\cline { 2 - 3 } & No & $\%$ & & & $5 \times 10^{2} \pm 8 \times 10$ \\
\hline Packed & 35 & 70 & $<10$ & $2.1 \times 10^{3}$ & $2.5 \times 10^{3} \pm 3 \times 10$ \\
\hline Unpacked & 42 & 84 & $1 \times 10^{2}$ & $1 \times 10^{4}$ & \\
\hline
\end{tabular}

Table 2: Incidence of mould species isolated from the examined smoked fish samples.

\begin{tabular}{|c|c|c|c|}
\hline \multirow[t]{2}{*}{ Mould species } & \multicolumn{2}{|c|}{ N0. of isolates } & \multirow[t]{2}{*}{ Total isolates (\%) } \\
\hline & Unpacked smoked fish & Packed smoked fish & \\
\hline Aspergillus spp & 39 & 52 & $91(67.4)$ \\
\hline A. niger & 20 & 18 & $38(28.1)$ \\
\hline A. flavus & 5 & 13 & $18(13.3)$ \\
\hline A. fumigatus & 7 & 10 & $17(12.6)$ \\
\hline A. ochraceus & 2 & 7 & $9(6.7)$ \\
\hline A. candidas & 5 & 4 & $9(6.7)$ \\
\hline Pencillium spp & 19 & 9 & $28(20.7)$ \\
\hline P. expansum & 12 & 9 & $21(15.6)$ \\
\hline P. viridicatum & 7 & 0 & $7(5.2)$ \\
\hline Mucor spp. & 0 & 3 & $3(2.2)$ \\
\hline Fusarium spp. & 0 & 4 & $4(3)$ \\
\hline Eurotium repens & 2 & 4 & $6(4.4)$ \\
\hline Cladosporium spp. & 1 & 2 & $3(2.2)$ \\
\hline Total & 61 & 74 & $135(100)$ \\
\hline
\end{tabular}

NB: Percentage was calculated according to the total number of mould isolates (135).

Table 3: Statistical values of total yeast count of the examined smoked fish samples ( $\mathrm{n}=50$ each). 
Assiut Vet. Med. J. Vol. 54 No. 117 April 2008

\begin{tabular}{|c|c|c|c|c|c|}
\hline \multirow{2}{*}{ Smoked fish } & \multicolumn{3}{|c|}{ Yeast count(cfu/g) } \\
\cline { 2 - 3 } & \multicolumn{2}{|c|}{ Positive } & Min & Max & Mean \pm SE \\
\cline { 2 - 3 } & No & $\%$ & & & $5.2 \times 10^{3} \pm 3 \times 10$ \\
\hline Packed & 50 & 100 & $3 \times 10$ & $3.5 \times 10^{4}$ & $1.2 \times 10^{3} \pm 2 \times 10^{2}$ \\
\hline Unpacked & 46 & 92 & $<10$ & $1.2 \times 10^{4}$ & \\
\hline
\end{tabular}

Table 4: Incidence of yeast species isolated from the examined smoked fish samples.

\begin{tabular}{|l|c|c|c|}
\hline \multirow{2}{*}{ Yeast species } & \multicolumn{2}{|c|}{ N0. of isolates } & \multirow{2}{*}{ Total isolates (\%) } \\
\cline { 2 - 3 } & Unpacked smoked fish & Packed smoked fish & \\
\hline Candida spp. & 34 & 48 & $82(61.6)$ \\
C. albicanis & 20 & 28 & $48(36.1)$ \\
C. lipolytica & 7 & 10 & $17(12.8)$ \\
C. tropicalis & 7 & 10 & $17(12.8)$ \\
\hline Saccharomyces spp. & 5 & 7 & $12(9)$ \\
\hline Rhodotroula spp. & 8 & 9 & $17(12.8)$ \\
\hline Debaryomyces spp. & 12 & 10 & $22(16.5)$ \\
\hline Total isolates & 59 & 74 & $133(100)$ \\
\hline
\end{tabular}

NB: Percentage was calculated according to the total number of yeast isolates (133).

Table 5: Proteolytic and lipolytic activities of fungi isolated from the examined smoked fish samples.

\begin{tabular}{|c|c|c|c|c|c|}
\hline \multirow[t]{2}{*}{ Isolated fungi } & \multirow[t]{2}{*}{ N0. of isolates } & \multicolumn{2}{|c|}{ Proteolytic } & \multicolumn{2}{|c|}{ Lipolytic } \\
\hline & & No. & $\%$ & No. & $\%$ \\
\hline A. niger & 38 & 33 & 86.8 & 20 & 52.6 \\
\hline A. flavus & 18 & 15 & 83.3 & 16 & 88.9 \\
\hline A. fumigatus & 17 & 12 & 70.6 & 12 & 70.6 \\
\hline A. ochraceus & 9 & 4 & 44.4 & 6 & 66.7 \\
\hline A. candidas & 9 & 3 & 33.3 & 5 & 55.6 \\
\hline P. expansum & 21 & 21 & 100 & 20 & 95.2 \\
\hline P. viridicatum & 7 & 7 & 100 & 7 & 100 \\
\hline Mucor spp. & 3 & 3 & 100 & 3 & 100 \\
\hline Fusarium spp. & 4 & 1 & 25 & 4 & 100 \\
\hline Eurotium repens & 6 & 2 & 33.3 & 6 & 100 \\
\hline Cladosporium spp. & 3 & 1 & 33.3 & 2 & 66.7 \\
\hline C. albicanis & 20 & 2 & 10 & 12 & 60 \\
\hline C. lipolytica & 7 & 1 & 14.3 & 7 & 100 \\
\hline C. tropicalis & 7 & 2 & 28.6 & 5 & 71.4 \\
\hline Saccharomyces spp. & 5 & 2 & 40 & 4 & 80 \\
\hline Rhodotroula spp. & 8 & 8 & 100 & 8 & 100 \\
\hline Debaryomyces spp. & 12 & 12 & 100 & 12 & 100 \\
\hline
\end{tabular}


The present data in Table (1) revealed the incidence of mould in the examined samples. Moulds were recovered from packed and unpacked smoked fish at a rate of $70 \%$ and $84 \%$, respectively. The mean mould counts were $5 \times 10^{2} \pm 8 \times 10$ and $2.5 \times 10^{3} \pm 3 \times 10 \mathrm{cfu} / \mathrm{g}$ for packed and unpacked examined smoked fish samples, respectively. The obtained findings are coincided with those recorded by Edris (1996) and Lashin (2004). The low moisture content of smoked fish favors the growth of mould (Connell, 1990). Mould contamination may be attributed to inadequate processing, recontamination or incorrect storage of herring after processing. In this respect Graikoski (1973) reported that smoked fish can be contaminated with mould mainly from contaminated chamber and wood smoke as well as dust used in fish smoking. The relatively higher mould count of unpacked smoked fish samples may be attributed to continuous contamination of the fish through frequent handling and to the general poor sanitary condition of many markets.

The examined smoked fish samples harbored more mould genera and species (Table 2). Aspergillus and Pencillium spp. were the dominant groups irrespective of the packed or unpacked samples. Out of the 135 moulds isolated from the packed and unpacked smoked fish samples, $A$.niger was the dominant with an incidence of $28.1 \%$ of the total mould isolates. Aspergillus flavus and Penicillium expansum were also frequently isolated. Other moulds isolated were Cladoporium, Eurotium, Fusarium and Mucor species. The obtained results of the isolated moulds are in agreement with those obtained by Munimbazi and Bullerman (1996); Pangi et al. (1990) and Yousef (1998).

It is worthwhile from the recorded results that most of the isolated moulds are toxigenic types and have the ability to produce mycotoxins whenever the conditions are right and become of public health hazard. A. flavus is known to produce aflatoxins, while $P$. expansum and $P$. viridicatum produce penicillic acid and ochratoxin respectively when cultured on organic substrates (Joffe, 1965). Of the remaining genera, Eurotium repens have been associated with the production of sterigmatocystin. Fusaria species produces trichothecenes and zearalenone (Davis and Diener, 1978 and Marasas et al., 1979) while Cladosporium species are known to produce epicladosporic acid and fagicladosporic acid (Joffe 1965).

Yeasts were recovered from packed and unpacked smoked fish at a rate of $100 \%$ and $92 \%$, respectively (Table 3 ). The mean yeast count of the examined samples were $5.2 \times 10^{3} \pm 3 \times 10$ and $1.2 \times 10^{3} \pm 2 \times 10^{2}$ $\mathrm{cfu} / \mathrm{g}$ for packed and unpacked smoked fish samples, respectively. The 
present results coincide with that reported by El- Sayed (1995). In this concern, Nickelsen and Finne (1992) reported that yeast form a significant proportion of the spoilage flora in smoked products, with high heat in put where yeasts are the more stable organisms that will be predominant. It is obviously that the high incidence of yeast contamination was noticed in packed smoked fish, packing may increase contamination by yeasts. Similar findings were reported by Kemp et al. (1986).

Dealing with the isolated yeast species, the achieved results in Table (4) showed that the predominant yeast species isolated from the examined samples was Candida spp. Out of 133 yeast isolates, 22(16.5\%) were belonging to Debaryomyces spp., 17(12.8\%) were belonging to Rhodotroula spp. and 12(9\%) were belonging to Saccharomyces spp., while Candida spp. comprised the remaining $61.7 \%$. Such isolated yeasts could be recovered by other investigators from smoked fish (Ibrahim, 2000 and Lashin, 2004). The isolated yeast species were mentioned as spoilage organisms of smoked fish with undesirable changes during prolonged storage (Coni et al., 1994). From the public health point of view the most predominant yeast species was Candida albicanis $(36.1 \%)$ which constitute a public health hazard as involved in several allergic conditions, pulmonary infection, vulvovaginitis, endocarditis, meningitis and occasionally fatal systemic disease (Kwon- Chung and Benett, 1992).

\section{Proteolytic activity of isolates}

The results recorded in Table (5) pinpoint that most of the isolated fungi have a proteolytic potential. Their proteolytic activity however varies among the isolates. Among the isolates, strains of $P$. expansum and $P$. viridicatum and Mucor spp. demonstrated the most noticeable proteolytic activity (100\%), followed by strains of $A$. niger (86.8\%) and A. flavus (83.3\%). On the other hand, A. fumigatus, A. ochraceus and A. candidas showed relatively lower percentage of proteolytic activities. Cladosporium spp, Eurotium repens and Fusarium spp. exhibited low proteolytic activities, and were not frequently isolated. Among the isolated yeasts, Rhodotroula spp. and Debaromyces spp. showed the most noticeable proteolytic activity (100\%). Candida spp. and Saccharomyces spp. showed low percentage of proteolytic activities ranged from 10-40\%. The obtained results agreed to certain extent with those reported by other investigators (Yousef, 1998; Sayid, 1999; Lashin, 2004). 
Proteinases are a well known group of proteolytic enzymes that play an important role in food processing industry, they are considered among the most important enzymes in the breakdown of fish materials when fungi attack their surface (Ward, 1985). The ability of the isolates to elaborate protease is an indication of their active role in the spoilage of smoked fish. The level of proteolytic microorganisms may be of value to predict refrigerated storage life and to assess processing methods (Lee and Kraft, 1992).

\section{Lipolytic activity of isolates}

The data recorded in Table (5) declared that the incidence of lipolytic activity was high in most of the examined isolates. Among the mould isolates, strains of $P$. expansum, $P$. viridicatum, Mucor spp., Fusarium spp., Eurotium repens were showed lipolytic activities with a percentage reach up to 95-100\%. Aspergillus spp. and Cladosporium spp. showed lipolytic activity with an incidence ranging from 52.6- 88.9\%. The tested yeast isolates showed lipolytic activity with an incidence ranged from 60-100 \%. The obtained results are in accordance with that recorded by other investigators (Banwart, 1980, Godtfred, 1990, Sallam et al., 1991 and Vanot et al., 2001).

Fungi are known to induce certain objectionable changes in the fat content of fish rendering them unmarketable or even unfit for consumption (Smith and Hass, 1992). The rancidity of smoked fish when stored for long time at a relatively high temperature is mainly due to lipase enzyme produced by lipolytic moulds (Watanabe and Dzekedzeke, 1971). Fungal contamination is considered the main spoilage agent of smoked fish which lead to impart musty off flavors, sliminess, lipolysis and unpalatable taste (Welthagen and Viljoen, 1999).

Smoked fish is now a product of general consumption. The spoilage of smoked fish during storage is considered an important and dangerous problem facing smoked fish producers. The risk coming from fungal growth in relation to smoked fish that all parameters required for mould growth are available specially where the product badly packed, not protected from environment and stored at ordinary room temperature. The existence of moulds and yeasts that can produce proteases and lipase in smoked fish strengthened the possibility of smoked fish to undergo spoilage, unmarketable or even unfit for human consumption that may constitute a public health hazard and economic losses. Fungal contamination of smoked fish should be viewed with serious concern because of the ability of the moulds to produce mycotoxins, some of which are very dangerous and lethal to humans 
even in small doses. Proper storage of smoked fish is also necessary because poor storage methods and unhygienic handling of the items are known to predispose them to fungal contamination.

\section{REFERENCES}

AFDO (1991): Association of Food and Drug Officials, June. Cured, salted, and smoked fish establishments good manufacturing practices: Association of Food and Drug Officials. 7 p.

Andrews, W.H. and Hammack, T.S. (1998): Food sampling and preparation of sample homogenate. In Food and Drug Administration, Bacteriological Analytical Manual Online. Ch. 4. Available: http://www.cfsan.fda.gov/ ebam/bam-4.html.

Banwart, G.J. (1980): "Basic Food Microbiology". AVI. Publishing Company, INC. West Port, Connecticut.

Campbell, M.C.; Stewart, J.L. and Larsh, H.W. (1980): "The Medical Mycology". $2^{\text {nd }}$ Ed., Chi Chester- Brishone, Toronto.

Coni, G.; Cantoni, C.; Rosa, M. and Cattaneo, P. (1994): Yeast and fish deterioration. Ristor. Collett., 9: 65-73.

Connell, J.J. (1990): "Control of fish quality" $3^{\text {rd }}$ Ed. Formerly of Tory Research Station, Aberdeen, Scotland.

Davis, N.D. and Diener, U.L. (1978): Mycotoxins. In. Food and beverage mycology. R. Beuchat (ed.) AVI Publishing Co. West Port C. T.

Edris, A.M. (1996): Microbial evaluation of some marketed smoked fish. Zag. Vet. J., 24: 76- 81.

El- Sayed, Y.S.A. (1995): Mycological studies on locally produced smoked fish. Ph. D. Thesis .Dept. of Food Control, Fac. of Vet. Med. Zagazig Univ., Egypt.

Godtfred, S.E. (1990): Microbial lipases. In Microbial enzymes and biotechnology. pp. 225-274, $2^{\text {nd }}$ Ed. (W. M. Fogarty and C. T. Kelly, Ed.) Elsevier, London.

Graikoski, J.T. (1973): Microbiology of cured and fermented fish. In Chi Chester, C.O. and Graham, H. D. (Ed.): Microbial safety of fishery products. Acad. Press. New York and London.

Ibrahim, H.A.M. (2000): Incidence of fungal contaminants in fish products. M. V. Sc., Thesis, Zag. Benha, Egypt.

ICMSF(1978): "Microorganisms in Food" Vol. 1, Their significance and methods of enumeration. $2^{\text {nd }}$ Ed., Univ. of Toronto Press, Toronto, Canada.

Joffe, A.Z. (1965): Mycotoxins in Foodstuffs. MIT. Press Cambridge pp. $111-132$. 
Kemp, J.D.; Langlois, B.E.; Fox, J.D. and Nicastro, F. (1986): Quality of dry -cured hams produced from pre- frozen hams as affected by mechanical tenderization and vacuum packing. J. Food Prot., 49: 417-420.

Koburger, J.A. and Jaeger, K.E. (1987): Specific and sensitive plate for assay for bacterial lipase. Appl. Environm. Microbiol., 53: 211.

Kobatake, M.; Kreger-Van Rij, N.J.W. and Pacido, T.L.C. (1992): Isolation of proteolytic psychrotrophic yeasts from fresh raw sea foods. Lett. Appl. Microbiol., 14: 37- 42.

Kwon- Chung, K.J. and Benett, J.E. (1992): "Medical Mycology". Lea and Febiger, Philadelphia, London.

Lashin, E.M. (2004): Study on mycological quality of fish. Ph. D. Thesis. Dept. of Meat Hygiene, Fac. of Vet. Med. Cairo Univ., Beni Suef Branch.

Lee, J.S. and Kraft, A.A. (1992): "Compendium of Methods for the Microbiological Examination of Food". Ch.12, $3^{\text {rd }}$ Ed., pp. 193198. Ed. by Vanderzant and Splittstoesser. Compiled by APHA Technical Committee.

Marasas, W.F.O.; Leistner, L.; Hijniann, G. and Eckardt, C. (1979): Occurrence of toxigenic strains of Fusarium in maize and barley in Germany. European J. Appl. Microb. Biotech., 7: 289 -305 .

Munimbazi, C. and Bullerman, L.B. (1996): Mould and mycotoxins in food from Burundi. J. Food Prot., 59: 869-875.

Nickelsen, H.R. and Finne, G. (1992): "Fish, crustaceans and precooked sea foods" Ch. 4,. In APHA: Compendium of methods for the microbiological examination of food. $3^{\text {rd }}$ Ed., Washington D. C., USA.

Okafor, N. and Nzeako, B.C. (1985): Microbial flora of fresh and smoked fish from Nigerian Fresh Water. F. Microbiol., 2: $71-75$.

Pangi, L.O.; Opoye, I. and Itoua, O. (1990): Smoked fish and mycological problems in the Peoples Republic of the Congo. Bulletin-de la- Socite. Francaise- de -Mycologic Medical, 19, (1): 67-70.

Pitt, J.I. and Hocking, A.D. (1985): "Fungi and food spoilage". Academic press. New York.

Raper, K.B. and Fennel, D.I. (1965): The genus Aspergillus. Williams and Wilkins Co. Baltimore. MD. 
Sallam, S.S.; Hafez, N.M.; El-Shinawy, S.H. and El- Koly, A.M. (1991): Lipolytic organisms in an Egyptian cheese. Beni Suef Vet. Med. Res., 1: 339-405.

Samson, R.A.; Hoekstra, E.S. and VanOoorschat, C.A.N. (1981): Introduction to foodborne fungi. Centraalbureau Voor Schimmelcultures Baarn, Holland.

Sayid, A.A.K. (1999): Proteolytic fungi in some meat products: Their incidence and methods for inhibition. M.V. Sc. Dept. of Meat Hygiene, Fac. of Vet. Med. Assuit Univ.

Smith, J. and Hass, M.J. (1992): lipolytic microorganisms, Ch. 11. In APHA: Compendium of Methods for the Microbiological Examination of Food. $3^{\text {rd }}$ Ed. Washington, USA.

Stoskopf, M.K.; Phelps, T.H. and Baucer, B.A. (1993): "Fish Medicine". $9^{\text {th }}$ Ed., W. B. Saunders Co., Philadelphia, pp. 563.

Tournas, V.; Stack, M.E.; Mislivec, P.B.; Koch, H.A. and Bandler, R. (2001): Yeasts, Molds, and Mycotoxins. In Food and Drug Administration, Bacteriological Analytical Manual Online. Ch. 18. Available at http://www.cfsan.fda.gov/ ebam/bam18.html.

Vanot, Deyris, V.; Guilhem, M.C.; Phan, T. and Comeau, L.C. (2001): Optimal design for the maximization of Pencillium cyclopium lipase production. Appl. Microbiol. Biotechnol., 57: 342-345.

Ward, D.R. (1985): Hydrolytic enzymes. In Comprehensive Biotechnology. The Principles, Application and Regulation of Biotechnology in Industry, Agriculture and Medicine. Vol. 3, H. W. Blanch, S. Drew and DIC. Wang, Ed., Pergamon, Oxford, pp. 819-835.

Ward, D.R. and Baaji, N.J. (1988): Factors affecting microbiological quality of sea foods. Food Technol., 42: 85-89.

Watanabe, K. and Dzekedzeke, O. (1971): Taste preference of Zambians for various types of dried and smoked fish. Fish Res. Bull. Zambia, 5: 199-206.

Welthagen, J.J. and Viljoen, B.C. (1999): The isolation and identification of yeasts obtained during the manufacture and ripening of chedder cheese. Food Microbiol., 16: 63- 73.

Wu, M.T. and Salunkhe, D.K. (1978): Mycotoxin producing potential of fungi associated with dry shrimps. Appl. Bacteriol., 45, 232 238. 
Yousef, H.H.E. (1998): Mycological status for salted, smoked and frozen mackerel in Assuit Governorate. Ph. D., Fac. of Vet. Med. Assuit Univ. 